\title{
Economic efficiency of innovation in the resto- ration of soil resources in organic agricultural production
}

\author{
Ludmila Kachanova, ${ }^{1, *}$ and Anatoly Bondarenko ${ }^{2}$ \\ ${ }^{1}$ Don State Technical University, 344002, Gagarina sq., 1, Rostov-on-Don, Rostov region, Russia \\ ${ }^{2}$ Azov-Black Sea Engineering Institute, 347740, Don State Agrarian University, Lenina st., 21, \\ Zernograd, Rostov region, Russia
}

\begin{abstract}
The intensification of the use of the main means of agricultural production dictates the need to restore and increase soil fertility. The purpose of the study is to develop a methodological basis for calculating the economic efficiency of innovation in the restoration of soil resources in organic agricultural production with an assessment of its practical implementation in the conditions of arid agriculture in the south of Russia. To prevent the loss of a significant part of soil resources, their restoration, an innovative approach to organotransformation in the restoration of soil resources has been developed. The proposed approach allows integrating organic farming and animal husbandry with the processes of restoration of soil resources for the implementation of organotransformation of soil formers in degraded soil resources. In the methodology for determining the economic efficiency of the innovative approach of organotransformation, five modifications are proposed. The implementation of the recommended modification provides for the lowest costs for the restoration of soil resources, a sufficient level of fertility for obtaining high yields, the net income is about 27 thousand rubles/ha or 454 rubles/c. The application of the developed approach confirms the economic feasibility of innovation in the agricultural sector of the economy in organic agriculture.
\end{abstract}

\section{Introduction}

Currently, there are more than 385 million hectares of agricultural land in the Russian Federation, of which about 196 million hectares are agricultural land. According to the Department of Land Reclamation of the Ministry of Agriculture of the Russian Federation, about 130 million hectares are degraded soils. The rate of degradation is about 1.5-2 million hectares per year.

Almost half of the degraded land is concentrated in the southern regions of the country. This is more than 56 million hectares of arable land with a low humus content. Over the past 100 years, the humus content in the soils of the southern regions of Russia has de-

\footnotetext{
* Corresponding author: kachanovakls@mail.ru
} 
creased by $30-40 \%$. At present, the annual reduction in humus is observed on average at the level of $0.62 \mathrm{t} / \mathrm{ha}$. With a conditional conversion, we observe a reduction in the humus layer by about $0.005 \mathrm{~cm}$ per year (the specific weight of humus in the soil is about 1.25-1.4 $\mathrm{g} / \mathrm{cm}^{3}$ ). It is known that a decrease in the humus horizon of soil resources by $1 \mathrm{~cm}$ leads to a decrease in the yield of agricultural crops by 1 centner/ha [1-3].

Only with the use of innovation in this direction of development, within the framework of the transformation of new knowledge and technologies into the processes of biologization of agricultural production, it is possible to increase the level of fertility of soil resources, achieve a deficit-free balance of humus, and increase crop yields. It is extremely important to increase the level of fertility not by destroying, but by restoring, reproducing soil resources [4-6].

The aim of the study is to develop methodological foundations for calculating the economic efficiency of innovation in the restoration of soil resources in organic agricultural production with an assessment of its practical implementation in the conditions of arid agriculture in the south of Russia.

\section{Materials and research methods}

In the context of the development of innovation in the agricultural sector of the economy, the issues of improving the management of innovative processes in organic agriculture are important. The introduction of highly effective methods of managing innovative processes in the agricultural sector determines the importance of a systematic approach in solving the assigned tasks.

The systematic approach serves as the basis for studying the interaction of the main branches of the agricultural sector - crop production and animal husbandry in their biologization. In the management of innovation processes, the leading role belongs to the organization of organic farming and organic animal husbandry (Figure 1). 


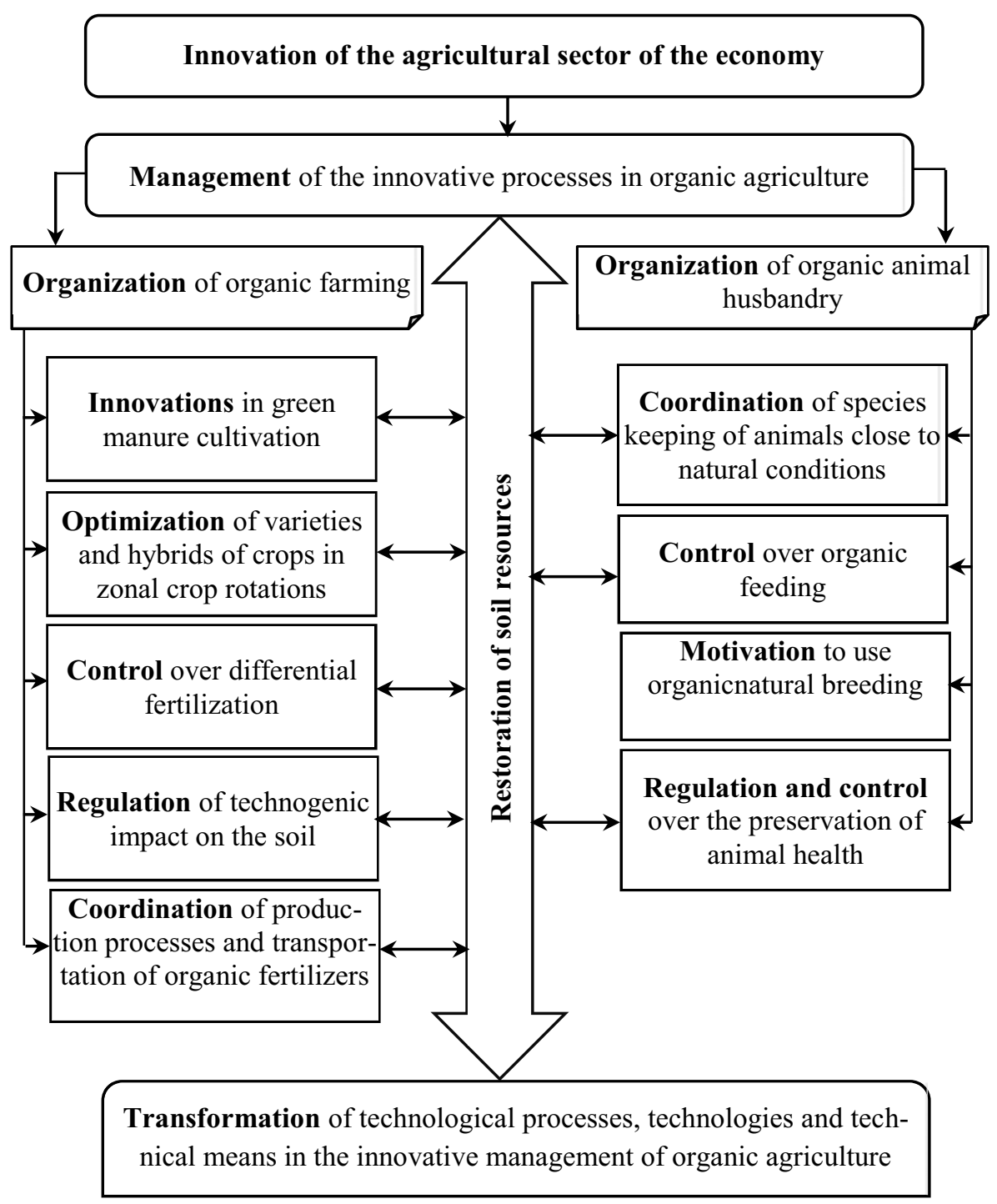

Fig. 1. The essence of innovation in the agricultural sector of the economy through the functions of managing innovation processes in organic agriculture

The implementation of the elements of the systems of organic livestock raising and farming is possible only with the availability of the main means of production - land. The values of the output indicators of these systems, such as the yield of agricultural crops, the productivity of animals and poultry, directly depend on the qualitative and quantitative parameters of soil resources, primarily on the content of humus. Agricultural scientists note an intensive reduction in the humus content in the southern Russian ordinary chernozem. According to their forecasts, this priceless gift of nature may be lost in 20-25 years [7-8].

In modern conditions of intensive agricultural production, the consumption of humus for the formation of the crop is significant, but its content in the soils is practically not restored. This is due to a decrease in the number of animals, especially cattle, and, as a consequence, a decrease in the output of manure, which is the main component for the produc- 
tion of organic fertilizers. At present, organic fertilizers are not applied to the soil in the required amount, and the by-product of plant growing - the non-grain part of the crop - is still far from being developed as an organic fertilizer [9-11].

To prevent the loss of a significant part of soil resources, their restoration and qualitative improvement of the properties of natural soils, an innovative approach to organotransformation in the restoration of soil resources has been developed. Innovation in the framework of management and organization of organic animal husbandry and agriculture is considered as an integral part of organic agricultural production (Figure 1). It is extremely important to introduce elements of an innovative approach to organotransformation of the restoration of soil resources in relation to the conditions of dry farming, which prevails in the grain-producing regions of southern Russia. Therefore, it is important to study and solve problems associated with the economic assessment and the effectiveness of the proposed innovative approach to organotransformation of the restoration of soil resources.

The following functions are distinguished in the structure of the organization of biological agriculture. The introduction of innovations in the cultivation of green manure crops, provide for their sowing simultaneously with harvesting in a direct way. Green manure crops are generally known as a source of replenishment of nutrients in the soil, carried out with the produced crop. Optimization of varietal material in zonal crop rotations, taking into account the specifics of natural and climatic conditions, soil characteristics, characteristics and characteristics of agricultural crops cultivation. Control over the differentiated application of mineral and organic fertilizers, which is currently the most important element of the precision farming system. Regulation of technogenic impact on the treated surface (soil resources) of running systems of power machines [12]. The most important element in the organization of organic farming is the coordination of the production and transportation of organic fertilizers. Deliberate minimization of the use of mineral fertilizers, pesticides, plant growth regulators assigns the main role in the processes of replenishment of soil nutrients, as well as the restoration of soil resources, organic fertilizers [13-14].

Thus, each of the considered elements of the organization of organic farming, as a function of managing the innovative processes of organic agriculture, is a part of the technological process of restoring soil resources based on a systematic approach to managing these processes [15-16].

Considering the organization of organic animal husbandry as a function of managing innovative processes in organic agriculture, it should be noted the coordination of animal husbandry in the form of exceptional rules for their humane keeping, restrictions on livestock and high requirements for premises (prohibition of overcrowding, requirements for the size of premises in depending on the type of animal, a ban on adherent content). Strict control over the feed base of animals is carried out. If possible, feeds of our own production are used, rations are formed taking into account the biological characteristics of animals (for example, feed of animal origin is not used in feeding ruminants). It is forbidden to use synthetic feed additives, amino acids, growth stimulants [16].

Motivation for the use of organic natural animal breeding is one of the functions of organic animal husbandry. We use our own selection of animals, during breeding, natural mating is used, however, artificial insemination is allowed in exceptional cases. The purchase of animals from non-organic enterprises is strictly regulated, carried out in accordance with the eco-EU 2003 directive $[17,18]$.

With the normalized keeping of animals, according to conditions close to natural, feeding and caring for them, regulation and control over the preservation of animal health is reduced to reducing the use of veterinary drugs and creating natural favorable conditions for life. When the life of the animal is threatened, the use of prohibited drugs is possible In this case, the animal is placed in quarantine, its milk does not go into general processing. 
After complete recovery, the animal returns to the general herd after a two-fold period of drug withdrawal from the body [19-21].

Keeping animals in conditions close to natural, organic nutrition, the preservation of their health are directly dependent on the state of soil resources.

The restoration of soil resources acts as a connecting link in the effective organization of organic farming and animal husbandry, demonstrating the implementation of a systematic approach in the management of innovative processes in organic agriculture.

Having identified the main elements of the organization of organic farming and organic animal husbandry, having broadly defined the functions of managing innovative processes in agriculture, we have determined their connections through the system of restoration of soil resources through a systematic approach. In this regard, highlighted the area of knowledge about production activities, which contributes to the transformation of technological processes, technologies and technical means into innovations, innovations that contribute to improving the efficiency of the functioning of the agricultural sector of the economy. An increase in efficiency is manifested in an increase in soil fertility, ensuring a deficit-free balance of humus, an increase in the yield of agricultural crops, stabilization of the ecological situation, and obtaining more environmentally friendly agricultural products.

\section{Research results}

An innovative approach to the economic efficiency of the restoration of soil resources in organic agricultural production is based on organotransformation, that is, the process of integrating organic elements (organic soil formers) into the degraded part of the soil cover in order to restore its production qualities (soil fertility, structure, etc.), that is, the transformation of newly introduced organic matter into organic matter of the soil cover.

Organic soil formers are high-molecular structures of humus-containing substances. When they enter the soil cover, organic soil formers perform the main task - they qualitatively improve the condition of the soil.

As an example, three types of soils are presented (chestnut, ordinary chernozems, Ciscaucasian-Kazan chernozems) with different humus content and varying degrees of erosion (Table 1). The initial information to determine the economic efficiency of soil restoration is based on the use of the degree of influence of erosion and dehumification on soil fertility.

Table 1. Erosion and dehumification of soils (initial data for calculating the economic efficiency of the restoration of soil resources)

\begin{tabular}{|l|c|c|c|}
\hline \multirow{2}{*}{ Degree of erosion } & \multicolumn{3}{|c|}{ Humus content in soil, \% } \\
\cline { 2 - 4 } & Chestnut soils & $\begin{array}{c}\text { Ordinary cher- } \\
\text { nozem }\end{array}$ & $\begin{array}{c}\text { Ciscaucasian } \\
\text { chernozems }\end{array}$ \\
\hline Non-eroded & $1.0-3.5$ & $1.0-3.5$ & $1.0-3.5$ \\
\hline Weakly eroded & $0.6-2.1$ & $0.7-2.5$ & $0.8-2.8$ \\
\hline Medium eroded & $0.4-1.4$ & $0.5-1.8$ & $0.6-2.1$ \\
\hline Heavily eroded & $0.2-0.8$ & $0.2-0.7$ & $0.3-1.1$ \\
\hline
\end{tabular}

The calculation of the economic efficiency of innovation in the considered subject area was carried out when determining the regenerated value of soil resources. The regenerated value is understood as the part of the value of soil resources arising from the action of organic soil formers in the organization of innovative processes for the restoration of soil resources.

In the context of the three types of analyzed soils (chestnut, ordinary chernozems, Ciscaucasian chernozems), the determination of the economic efficiency of innovatics, the restoration of soil resources is carried out within the framework of transitional stages: from strongly eroded to moderately eroded (stage I), from moderately eroded to slightly eroded 
(stage II), from slightly eroded in non-eroded (III stage). The conditions for the realized organotransformation are formalized in the form of a matrix (Table 2).

Table 2. Organotransformation matrix of soil resources

\begin{tabular}{|c|c|c|c|}
\hline \multirow{2}{*}{ Soil type } & \multicolumn{3}{|c|}{ Organotransformation stages } \\
\cline { 2 - 4 } & $\begin{array}{c}\text { Stage I - from highly } \\
\text { eroded soils to moder- } \\
\text { ately eroded }\end{array}$ & $\begin{array}{c}\text { Stage II - from moder- } \\
\text { ately eroded soils to } \\
\text { slightly eroded }\end{array}$ & $\begin{array}{c}\text { Stage III - from } \\
\text { slightly eroded soils } \\
\text { to non-eroded }\end{array}$ \\
\hline Chestnut soils & $0.8 \% \rightarrow 1.4 \%$ & $1.4 \% \rightarrow 2.1 \%$ & $2.1 \% \rightarrow 3.5 \%$ \\
\hline $\begin{array}{c}\text { Ordinary } \\
\text { chernozem }\end{array}$ & $0.7 \% \rightarrow 1.8 \%$ & $1.8 \% \rightarrow 2.5 \%$ & $2.5 \% \rightarrow 3.5 \%$ \\
\hline $\begin{array}{c}\text { Ciscaucasian } \\
\text { chernozems }\end{array}$ & $1.1 \% \rightarrow 2.1 \%$ & $2.1 \% \rightarrow 2.8 \%$ & $2.8 \% \rightarrow 3.5 \%$ \\
\hline
\end{tabular}

At each of the stages of organotransformation in the implementation of innovative processes of restoration of soil resources, the required amount of organic soil formers was determined to activate the processes of regeneration of soil resources to achieve a given level of humus content. The costs of the regeneration processes, the cost of the obtained soil resources are calculated and, as the difference between the indicated indicators, the regenerated cost of soil resources is determined. Calculations were carried out for each type of soil according to the stages of their organotransformation.

Table 3. Matrix of costs and regenerated cost by stages of organotransformation of soil resources

\begin{tabular}{|c|c|c|c|c|}
\hline \multirow{2}{*}{$\begin{array}{c}\text { Stages of } \\
\text { organotrans- } \\
\text { formation of } \\
\begin{array}{c}\text { Ciscaucasian } \\
\text { chernozems }\end{array}\end{array}$} & $\begin{array}{c}\text { Organic soil formers, } \\
\mathbf{k g} / \mathbf{t}(\mathbf{t} / \mathbf{h a})\end{array}$ & $\begin{array}{c}\text { Costs for the res- } \\
\text { toration of soil } \\
\text { resources, rub/ha }\end{array}$ & $\begin{array}{c}\text { The cost of soil } \\
\text { resources, } \\
\text { rub/ha }\end{array}$ & $\begin{array}{c}\text { Regenerated value } \\
\text { of soil resources, } \\
\text { rub/ha }\end{array}$ \\
\hline \multirow{2}{*}{ Stage I } & $11 / 39600$ & 396000 & 875160 & 479160 \\
\cline { 2 - 5 } & $21 / 75600$ & 756000 & 1670760 & 914760 \\
\hline $\begin{array}{c}\text { Stage I } \\
\text { changes }\end{array}$ & $21 / 75600$ & $\Delta$ cost $=360000$ & & $\Delta$ res $=435600$ \\
\hline \multirow{2}{*}{ Stage II } & $28 / 100800$ & 756000 & 1670760 & 914760 \\
\hline \multirow{2}{*}{$\begin{array}{l}\text { Stage II } \\
\text { changes }\end{array}$} & 1008000 & 2227680 & 1219680 \\
\hline \multirow{2}{*}{ Stage III } & $28 / 100800$ & $\Delta$ cost $=252000$ & & $\Delta$ res $=304920$ \\
\cline { 2 - 5 } & $35 / 126000$ & 1008000 & 2227680 & 1219680 \\
\hline $\begin{array}{l}\text { Stage III } \\
\text { changes }\end{array}$ & 1260000 & 2784600 & 1524600 \\
\hline
\end{tabular}

After analyzing the costs of the implementation of organotransformation for all types of soil resources present in the southern regions of Russia, calculating the regenerated cost, we formed a consolidated matrix that combined all stages of organotransformation, that is, the restoration of soil resources from the state of strongly eroded to the state of non-eroded (Table 4).

Table 4. Consolidated matrix of costs and regenerated cost by stages of organotransformation of soil resources

\begin{tabular}{|c|c|c|c|c|c|}
\hline \multirow{3}{*}{ Soil type } & \multicolumn{5}{|c|}{ Indicators characterizing the organotransformation of soil resources } \\
\hline & \multicolumn{2}{|c|}{$\begin{array}{c}\begin{array}{c}\text { Number of organic soil } \\
\text { formers }\end{array} \\
\end{array}$} & \multirow{2}{*}{$\begin{array}{l}\text { Costs for the res- } \\
\text { toration of soil } \\
\text { resources, rub/ha }\end{array}$} & \multirow{2}{*}{$\begin{array}{c}\text { The cost of } \\
\text { soil re- } \\
\text { sources, } \\
\text { rub/ha }\end{array}$} & \multirow{2}{*}{$\begin{array}{c}\text { Regenerated } \\
\text { value of soil } \\
\text { resources, } \\
\text { rub/ha }\end{array}$} \\
\hline & $\mathrm{kg} / \mathrm{t}$ & $\mathrm{t} / \mathrm{ha}$ & & & \\
\hline Chestnut soils & 8 & 28800 & 288000 & 636480 & 348480 \\
\hline
\end{tabular}




\begin{tabular}{|c|c|c|c|c|c|}
\hline & 35 & 126000 & 1260000 & 2784600 & 1524600 \\
\hline $\begin{array}{c}\text { Changes by } \\
\text { stage }\end{array}$ & & & $\Delta$ cost $=972000$ & & $\Delta$ res $=1176120$ \\
\hline $\begin{array}{c}\text { Ordinary } \\
\text { chernozem }\end{array}$ & 75 & 126000 & 1260000 & 2784600 & 1524600 \\
\cline { 2 - 6 } & & & $\Delta$ cost $=1008000$ & & $\Delta$ res $=1219680$ \\
\hline $\begin{array}{c}\text { Changes by } \\
\text { stage }\end{array}$ & 11 & 39600 & 396000 & 875160 & 479160 \\
\hline $\begin{array}{c}\text { Ciscaucasian } \\
\text { chernozems }\end{array}$ & 35 & 126000 & 1260000 & 2784600 & 1524600 \\
\hline $\begin{array}{c}\text { Changes by } \\
\text { stage }\end{array}$ & & $\Delta 3 \mathrm{aT}=864000$ & & $\Delta$ res $=1045440$ \\
\hline
\end{tabular}

The consolidated data of the analyzed soil types demonstrate the excess of the regenerated value of soil resources over the costs of their restoration. For all types of considered soils with their stage-by-stage (I, II, III stages) and complete (I-III stages) organotransformation, the regenerated cost of soil restoration during the first year exceeds the cost of their restoration (in terms of 1 ha) by $21,0 \%$.

According to the developed innovative technology for the restoration of soil resources, in subsequent years, the costs of regeneration processes are not required, and therefore there is an accumulation of the regenerated cost of soil restoration according to the integral dependence. The regenerated cost of soil creation in the second year exceeds the cost of their restoration by $58.7 \%$, in the third year - by $72.5 \%$, in the fourth year - by $79.3 \%$, in the fifth year - by $83.4 \%$. The resulting regenerated value of the restored soil resources is the economic basis for realizing their productivity.

\section{Results and discussion}

In a number of leading agricultural enterprises of the Rostov region, an organic system of agricultural production has been introduced. The platform for the application of organotransformation in the restoration of soil resources was the Sovetsky CJSC of the Neklinovsky District of the Rostov Region. According to the program of long-term experimental research, the following modifications of the innovative approach of organotransformation in the restoration of soil resources were tested.

The first modification is a one-time restoration of soil resources. During the year, a single organotransformation will allow the regeneration of soil resources from strongly eroded (humus content in chestnut soils $0.7 \%$, in ordinary chernozems $0.7 \%$ and in Ciscaucasian chernozems $1.1 \%$ ) to non-eroded ones with a humus content of $3.5 \%$ in all species soil. The economic efficiency of the modification was determined using the restored soil resources for the production of grain crops (Table 5).

The second modification of the innovative approach to organotransformation in soil restoration involves a three-year experiment. For three years for organotransformation, $30 \mathrm{t} / \mathrm{ha}$ of organic soil formers were introduced for the regeneration of soil resources from highly eroded (humus content in chestnut soils $0.7 \%$, in ordinary chernozems $0.7 \%$ and in chernozems of the Ciscaucasian countries $1.1 \%$ ) to non-eroded - dyed with a humus content of $3.5 \%$ in all types of soils. During the organotransformation, the restored soil resources were used for the cultivation of agricultural crops. The economic efficiency of growing grain crops on average for 3 years is presented in Table 5 .

The third, fourth and fifth modifications of the innovative approach provide for annual organotransformation in volumes of $10 \mathrm{t} / \mathrm{ha}, 20 \mathrm{t} / \mathrm{ha}$ and $30 \mathrm{t} / \mathrm{ha}$, respectively. Different volumes of applied organic soil formers, calculation of the cost of soil restoration and determination of the efficiency of cultivation of grain crops on these soils, made it possible to identify the economic feasibility of using innovative technology on different scales on dif- 
ferent types of soils.

Table 5. Economic efficiency of growing winter wheat on restored soils

\begin{tabular}{|l|c|c|c|c|c|}
\hline \multirow{2}{*}{ Performance indicators } & \multicolumn{5}{|c|}{ Modifications of an innovative approach to organ transformation in } \\
& $\mathbf{1}$ & $\mathbf{2}$ & $\mathbf{3}$ & $\mathbf{4}$ & $\mathbf{5}$ \\
\cline { 2 - 6 } & 20750,37 & 24250,37 & 24250,37 & 27750,37 & 31251,37 \\
Production costs, rub/ha, incl. & & 20750,37 & 20750,37 & 20750,37 & 20750,37 \\
- costs of growing winter & 20750,37 & 3500 & 3500 & 7000 & 10500 \\
$\begin{array}{l}\text { wheat } \\
\text { - soil restoration costs }\end{array}$ & 0 & & & & \\
\hline $\begin{array}{l}\text { Total costs: } \\
\text { - rub/ha }\end{array}$ & 20750,37 & 24250,70 & 24250,37 & 27750,37 & 31250,37 \\
- rub/c & 345,84 & 404,18 & 404,17 & 462,51 & 520,84 \\
\hline Production cost rub/ha & 48000,00 & 48000,00 & 48000,00 & 48000,00 & 48000,00 \\
\hline $\begin{array}{l}\text { Net income: } \\
\text { - rub/ha }\end{array}$ & 27249,63 & 23749,30 & 23749,63 & 20249,63 & 16749,63 \\
- rub/c & 454,16 & 395,82 & 395,83 & 337,49 & 279,16 \\
\hline $\begin{array}{l}\text { Change in the level of profita- } \\
\text { bility, \% }\end{array}$ & 30,84 & 92,37 & 60,37 & 61,98 & 71,68 \\
\hline
\end{tabular}

The results of the research made it possible to calculate the change in the level of profitability of the cultivation of winter wheat in areas with restored soil resources in relation to cultivation on soils not subject to organotransformation. According to the first modification, the profitability level increased by $30.84 \%$, the second modification, on the average for three years of organotransformation application, made it possible to increase the profitability of wheat cultivation by $92.37 \%$. The third and fourth modifications made it possible to obtain similar results of changes in the level of profitability $-60.37 \%$ and $61.98 \%$, respectively. The fifth modification, with the highest volume of organotransformation of soil formers in the amount of $30 \mathrm{t} / \mathrm{ha}$, made it possible to increase the yield by $71.68 \%$.

From the presented data, it can be seen that the fifth modification is the most expensive. The total cost is $31,250.37 \mathrm{rub} / \mathrm{ha}$ or $520.84 \mathrm{rub} / \mathrm{c}$, of which $10,500 \mathrm{rub} / \mathrm{ha}$ are spent on the restoration of soil resources. In second place in terms of costs is the fourth modification, where the volume of organic soil and vegetation used in organotransformation is $20 \mathrm{t} / \mathrm{ha}$. The total costs amounted to $27,750.37 \mathrm{rub} / \mathrm{ha}$ or $462.51 \mathrm{rub} / \mathrm{c}$, of which $7,000 \mathrm{rub} / \mathrm{ha}$ are related to the restoration of soil resources.

The second and third modifications of the innovative approach of organotransformation in the restoration of soil resources are characterized by similar costs. The total amount is $24,250.37$ rubles / ha or 404.18 rubles / c, of which the restoration of soil resources accounts for $3,500 \mathrm{rub} / \mathrm{ha}$.

The most promising is the first modification, which demonstrates the lowest costs for the cultivation of winter wheat, including the restoration of soil resources. The profitability of growing winter wheat on restored soil plots is $30 \%$ higher than on growing on soils not subject to organotransformation.

\section{Conclusions}

The restoration of degraded soil resources, the introduction of retired agricultural land into circulation is an urgent problem, the solution of which contributes to solving the problems of ensuring the economic and food security of the region and the state as a whole.

The proposed study developed an innovative approach to organ transformation in the resto- 
ration of soil resources. A method for calculating the economic efficiency is proposed, based on five modifications, which make it possible to estimate the required volume of organic soil formers, which is economically expedient to organotransform into degraded soil resources in order to restore them.

The proposed innovative approach, methodological aspects of assessing the economic efficiency have been tested in the production activities of the financially sustainable agricultural enterprise Sovetsky CJSC in the Neklinovsky district of the Rostov region. The results of the cultivation of winter wheat grown on restored soils, subject to organotransformation, demonstrate an increase in efficiency compared to cultivation according to traditional technology on soils with a low humus content.

The developed methodology for calculating the economic efficiency made it possible to determine the volume of application of organic soil formers, which will be economically expediently reflected in the costs of restoring soil resources and will pay off when selling winter wheat by increasing the yield.

\section{References}

1. A. Bogoviz, E. Semenova, I. Sandu, The Future of the Global Financial System: Downfall or Harmony. Cep. «Lecture Notes in Networks and Systems», 334-340 (2019) DOI: 10.1007/978-3-030-00102-5_35

2. M. Vasilchenko, I. Sandu, Scientific Papers. Series: Management, Economic Engineering and Rural Development, 1(20), 599 (2020)

3. A. Bogoviz, J. Ragulina, S. Lobova, J. Chutcheva, N. Bykovskaya, N. V. QualityAccess to Success, 2(19), 103-107 (2018)

4. A. Bogoviz, Growth Poles of the Global Economy: Emergence, Changes and Future Perspectives. Cep. «Lecture Notes in Networks and Systems», 227-233 (2020) DOI: 10.1007/978-3-030-15160-7_23

5. A. Nesmiyan, V. Chernovolov, A. Semenihin, V. Zabrodin, S. Nikitchenko, Research on crops journal, 3(19), 560-567 (2018)

6. N. Kuznetsov, N. Ukolova, S. Monakhov, Y. Shikhanova, A. Milovanov, Espacios, 7(41), 2 (2020)

7. N. Kuznetsov, N. Ukolova, S. Monakhov, Y. Shikhanova, Journal of Advanced Research in Law and Economics, 2(8), 490-495 (2017) DOI: 10.14505//jarle.v8.2(24). 19

8. V. Kurochkin, Russia in the Global Economy: Challenges and Development Institutions, 249-251 (2016)

9. E. Lipkovich, A. Bondarenko, I. Lipkovich, Research Journal of Pharmaceutical, Biological and Chemical Sciences (RJPBCS), 3(7), 751-760 (2016)

10. N. Zaitseva, A. Larionova, V. Filatov, E. Rodina, V. Zhenzhebir, I. Palastina, E. Povorina, Ekoloji, 106(27), 495-502 (2018)

11. V. Kurochkin, Moscow Economic Journal, 7, 8-11 (2020)

12. A. Bondarenko, E. Lipkovich, I. Lipkovich, Journal of Industrial Pollution Control, 1(33), 1163-1170 (2017)

13. B. Meskhi, N. Limarenko, V. Zharkov, B. Shapoval, Bulletin of the Don State Technical University, 4, 129-135 (2017) DOI: 10.23947/1992-5980-2017-17-4-129135 
14. N. Byshov, I. Uspensky, I. Yukhin, N. Limarenko, IOP Conference Series: Earth and Environ-mental Science. Voronezh State Agrarian University named after Emperor Peter the Great, 012069 (2020) DOI: 10.1088/1755-1315/422/1/012069

15. E. Khudyakova, M. Gorbachev, E. Nifontova, IOP Conference Series: Earth and Environmental Science, 012079 (2019) doi: 10.1088/1755-1315/274/1/012079

16. A. Subaeva, A. Nurullin, V. Vodyannikov, E. Khudyakova, V. Sorokin, The Journal of Social Sciences Research, Special, 5, 290-295 (2018) DOI: 10.32861/jssr.spi5.290.295

17. T. Gulyaeva, V. Savkin, E. Kalinicheva, O. Sidorenko, E. Buraeva, Journal of Environmental Management and Tourism, 8(32), 1789-1798 (2018) DOI: 10.14505/jemt.v9.8(32).19

18. O. Kusakina, N. Dovgotko, Lecture Notes in Networks and Systems, 129 LNNS, 435448 (2020) DOI: 10.1007/978-3-030-47945-9_49

19. N. Kuznetsov, N. Ukolova, S. Monakhov, Y. Shikhanova, Journal of Environmental Management and Tourism, 3(19), 606-611 (2017) DOI: 10.14505/jemt.v8.3(19).11

20. J. Korotkikh, J. Chutcheva, IOP Conference Series: Earth and Environmental Science, 012025 (2019) DOI: 10.1088/1755-1315/274/1/012025

21. V. Filatov, L. Kozlovskikh, V. Avtonova, N. Zaitseva, A. Larionova, S. Maykova, N. Vikhrova, Ekoloji, 107(28), 267-273 (2019) 